\title{
Acute Upper Digestive Bleedings in Hospital in Bamako
}

\author{
MY Dicko1 ${ }^{*}$, Doumbia K. Wife Samake1, Sow H. Wife Coulibaly ${ }^{1}$, G. Soumaré2, MS Tounkara1, \\ D. Katilé1, 0. Mallé1, H. Guindo', Sanogo SD. Wife Sidibé1, A. Maiga1 , A. Konate1, MT Diarra1, \\ MY Maiga ${ }^{1}$
}

\author{
${ }^{1}$ Hepatogastroenterology Department, CHU Gabriel Touré, Bamako, Mali \\ ${ }^{2}$ Department of Internal Medicine of the Point G Hospital Unit, Bamako, Mali \\ Email: *dickmy9@yahoo.fr
}

How to cite this paper: Dicko, M., Samake, D.K.W., Coulibaly, S.H.W., Soumaré, G., Tounkara, M., Katilé, D., Mallé, O., Guindo, H., Sidibé, S.S.W., Maiga, A., Konate, A., Diarra, M. and Maiga, M. (2018) Acute Upper Digestive Bleedings in Hospital in Bamako. Open Journal of Gastroenterology, 8, 387-393. https://doi.org/10.4236/ojgas.2018.811040

Received: September 17, 2018

Accepted: November 2, 2018

Published: November 5, 2018

Copyright $\odot 2018$ by authors and Scientific Research Publishing Inc. This work is licensed under the Creative Commons Attribution International License (CC BY 4.0).

http://creativecommons.org/licenses/by/4.0/

(c) (i) Open Access

\begin{abstract}
The main objective of this work was to update the data on the epidemiological, clinical, etiological and prognostic aspects of these acute upper digestive hemorrhages. It was a prospective study for a period of 11 months (from March 2013 to January 2014) at the digestive endoscopy center of Gabriel Touré University Hospital in Bamako. At the end of this study, 63 patients had acute upper digestive bleeding (AUDB) among 954 hospitalized patients, that is to say a frequency of $6.7 \%$. The sex ratio was 3.5. The average age of our patients was $45 \pm 16.57$ years with extremes of 15 and 84 years. A notion of smoking, epigastralgia and none steroid anti-inflammatory drugs (NSAIDs) were more reported in the history with respectively 14 patients (22.3\%), 10 patients (15.9\%) and 4 patients (6.3\%), but haematemesis had occurred in 24 (38.1\%) patients without any antecedent. The main causes of hemorrhage were rupture of oesophageal varices in $34(57.6 \%)$ patients and peptic ulcers in 18 (30.5\%) patients. Early recurrence occurred in $7(11.1 \%)$ patients resulting in the death of 5 patients for an overall mortality of 9 patients among 63 (14.3\%). Acute high digestive hemorrhages are always serious. The correct management of the hemorrhagic episode by haemostatic gestures when available and the causes of haemorrhage improve the prognosis.
\end{abstract}

\section{Keywords}

Upper Digestive Bleeding, Etiology, Evolution, CHU Gabriel Touré

\section{Introduction}

Acute upper digestive bleeding (AUDB)) is a medico-surgical emergency that deserves a careful management regardless of its abundance and mode of revelation. 
It remains, despite all the technical progress, a real vital threat because the global mortality still remains from $5 \%$ to $30 \%$ according to the series [1] [2].

According to French studies, its annual incidence is roughly estimated about 100 to 150 episodes per 100,000 inhabitants [2] [3].

In another French study conducted, the main causes were gastroduodenal ulcers (30.27\%), portal hypertension (26.8\%) and oesophagitis (21.57\%) [4].

In Africa hospital frequencies reported from different countries are almost comparable with those 5.3\% in Tunisia, 3.6\% in Morocco, 1.2\% in Burkina-Faso, $3.1 \%$ in Madagascar and 7.3\% in Togo, 2\% in Benin [5]-[10].

In Mali, this subject has been reported by none recent several studies [11] [12] [13] [14]. Since AUDB is still a common finding in our context, we conducted this study to update data on their epidemiological, clinical, etiological and prognostic aspects.

\section{Patients and Methods}

The study was prospective in the hepato-gastroenterology teaching department of Gabriel Touré hospital in Bamako, from March 2013 to January 2014.

We included all patients having Acute Upper Digestive bleeding externalized by hematemesis, rectorragie or melena or the association of the three signs in the period of the study without any other criteria.

Patients were interviewed for a history of blood transfusion, jaundice, toxic use (tobacco, alcohol, gastrotoxic drugs).

The examination appreciated the signs of portal hypertension and hepatocellular deficiency and haemodynamic repercussion of the haemorrhage.

Upper digestive endoscopy after hemodynamic stabilistion allowed searched the cause of the bleeding and the stigmata of recent bleeding.

Hemoglobin and hematocrit levels were assessed for blood spoliation in order to decide blood transfusion.

The early evolution was appreciated by hemorrhage stopping or its recurrence of or the death of the patient.

All data were collected on a survey form and analyzed on epi-info (version 6.0). The Chi-square test was used to compare our results which were significant for a probability $\mathrm{p}<0.05$.

\section{Results}

During our study, 63 patients presented AUDB among 954 hospitalized patients that is to say a frequency of $6.7 \%$.

The male sex was predominant with 49 patients (77.8\%) against 14 women (22.2\%), a sex ratio of 3.5 .

The average age was $45 \pm 16.57$ years with extremes of 15 and 84 years.

The age group from 46 to 55 was more represented with 15 cases (23.9\%) (Table 1).

Shopsellors, farmors and housewives accounted for $63.5 \%$ of the sample. 
Table 1. Age group.

\begin{tabular}{ccc}
\hline Age group & Number & Percentage \% \\
\hline $15-25$ & 8 & 12.7 \\
$26-35$ & 11 & 17.4 \\
$36-45$ & 12 & 19 \\
$46-55$ & 15 & 23.9 \\
$56-65$ & 10 & 15.9 \\
$66-75$ & 4 & 6.3 \\
$76-85$ & 3 & 4.8 \\
Total & 63 & 100 \\
\hline
\end{tabular}

Tobacco use, epigastralgia and gastrotoxic drug use were more reported in the history with respectively 14 (22.3\%), 10 (15.9\%) and 4 (6.3\%) patients. However, hematemesis occurred in $24(38.1 \%)$ patients without any historic antecedent (Table 2). No known cases of hepatopathy or peptic ulcer (PU) have been reported.

At the admission, dizziness, asthenia, decreased blood pressure, and acelerated pulse were the most common signs of intolerance (Table 3 ). The physical examination reported pallor (48 patients), ascites (19 patients), jaundice (15 patients), hepatic encephalopathy (11 patients), splenomegaly (10 patients), hepatomegaly (06 patients) and collateral venous circulation (CVC) (06 patients).

The upper digestive endoscopy preferred in the first 6 hours or even 24 hours was the most often performed beyond 24 hours.

Esophageal varices (EV) and peptic ulcer (PU) were the most common endoscopic lesions, respectively 34 cases $(57.6 \%)$ and 18 cases (30.5\%) (Table 4). Cirrhosis has been exclusively the cause of portal hypertension (PHT). Four patients died before upper gastrointestinal endoscopy, were retained in the study for epidemiological and clinical data.

A blood transfusion was performed in 39 patients with an average of 2.4 blood bags of $250 \mathrm{ml}$ (range $1-4$ pouches) but it did not influence the prognosis ( $\mathrm{p}=$ 0.8308). Any endoscopic haemostasic treatment was performed because it is not available in the context of the study.

The spontaneous bleeding stopping was observed in 46 patients (73\%) and early recurrence occurred in 7 patients (11.1\%) including 4 EV breaks, $2 \mathrm{PU}$ and traumatic lesion of the esophagus. Global mortality was $9 / 63$ patients (14.3\%) including 4 patients who could not be explored (cited above) and 5 cases of early haemorrhagic recurrence ( 2 cases of rupture of EV, 2 cases PU, one traumatic lesion case of the esophagus).

\section{Discussion}

The limitation of the study was the number of the sample and some patients had low financial possibility to assess the liver disease. Four patients died before 
Table 2. Patient history.

\begin{tabular}{ccc}
\hline Historic & Number & Percentage \% \\
\hline AHT & 6 & 9.5 \\
Diabetese & 1 & 1.6 \\
Epigastrics & 10 & 15 \\
Hematemesis & 6 & 9.5 \\
Jaundice & 8 & 12.7 \\
Alcohol & 4 & 6.3 \\
Tobacco & 14 & 22.3 \\
NSAIDs & 4 & 6.3 \\
Schistomiasis & 4 & 6.3 \\
HIV & 1 & 1.6 \\
Tuberculosis & 1 & 1.6 \\
None & 24 & 38.10 \\
\hline
\end{tabular}

AHT: arterial hypertension; NSAIDs: none steroïd anti-inflammatory drugs.

Table 3. Signs of intolerance at admission.

\begin{tabular}{ccc}
\hline Signs & Number & Percentage \% \\
\hline Dizziness & 34 & 54 \\
Asthenia & 23 & 36.5 \\
Ear buzzing & 2 & 3.2 \\
Headache & 3 & 4.8 \\
Ear buzzing + Headache & 1 & 1.6 \\
Blood pressure $<10$ & 24 & 38.1 \\
Pulse $>100$ & 30 & 47.6 \\
\hline
\end{tabular}

Table 4. Lesions found at endoscopy.

\begin{tabular}{ccc}
\hline Lesions & Frequency & Percentage\% \\
\hline Esophageal varices (EV) & $34^{*}$ & 57.6 \\
Peptic ulcer (PU) & $18^{*} 1$ & 30.5 \\
HTP gastropathy & 1 & 1.7 \\
Antral vascular ectasia & 1 & 1.7 \\
Acute lesions of the mucous membrane & 1 & 1.7 \\
Mallory Weiss & 2 & 3.4 \\
gastric tumor & 3 & 5.1 \\
Traumatic cardiac lesion by fishbone & 1 & 1.7 \\
Normal & 2 & 3.4 \\
\hline
\end{tabular}

${ }^{\star}$ Both lesions were associated with some patients; ${ }^{\star} 1$ gastric seat: 12 cases; Duodenal seat: 6 fish case. 
digestive endoscopy and the causes of the bleeding did not reported in theses cases. We collected 63 cases of upper gastrointestinal bleeding, which accounted for $6.7 \%$ of hospitalizations over an 11-month period. This frequency is considerable in a context where the means of haemostasis (pharmacological and endoscopic) are not available. However, the data collected made it possible to evaluate the epidemiology, the clinical picture, the etiologies and the prognosis of these haemorrhages. This frequency is similar to those found by Diarra et al. [13] and Bagny et al. [9] which were respectively $5.55 \%$ and $7.32 \%$, but higher than those found in some African studies between $2 \%$ and $3 \%, 6 \%$ [6] [7] [8] [10].

These differences in frequency can be explained by a recruitment bias because of the durations of the studies are not identical.

The male predominance of gastrointestinal bleeding is reported in several African series [6] [7] [8] [9] [11] [13] [15] probably related to the easy access of men to the toxic (tobacco, NSAID). In addition, the high incidence of PHT-producing liver disease is reported in humans [11].

The average age of occurrence of gastrointestinal bleeding in our study (45 years) is similar to that of some African studies that were 48 years [6] and 47.45 years [13] but lower than that found by Zohra 51 years [16].

The high prevalence among farmers and housewives could be explained by the promiscuity that favors the human-to-human transmission of the hepatitis B virus. This fact is justified by the frequency of EV rupture caused by PHT in relation to cirrhosis. B. Horizontal transmission, horizontal transmission, inter-individual of this virus is known. Tobacco was the most recovered toxicant with $22.3 \%$ of cases and could intervene in the determinism of PU frequently found in this study and explained the male predominance. The gastro-toxic drugs were found in our study in $6.3 \%$ of cases comparable to the frequency of Razafimahefa et al. which was 7.6\% [8] but lower than that of Bagny et al. which was $17 \%$ [9]. The signs of intolerance of anemia were found in most of our patients and this finding was reported by N'Tagirabiri et al. [15] and Razafimahefa et al.

Rupture of oesophageal varices was the leading cause of upper digestive haemorrhage found in $57.6 \%$ of cases followed by peptic ulcer with $30.5 \%$ of cases, most likely because of the frequency of infection with the gastrointestinal ulcer HBV and Helicobacter pylori infection in the general population. This finding confirms the study by Diarra et al. [13] who found respectively $55.2 \%$ and $12.8 \%$. These results are different from those of N'Tagirabiri et al. (28.2\% and $46.1 \%)$ [15] and Razafimahefa et al. [8] who found $40.32 \%$ PU and 38.76 indeterminate causes. In our study, no lesion in digestive endoscopy was found in $3.4 \%$ of cases, probably due to fugitive lesions by NSAIDs justifying the early inputs of endoscopy.

Rupture of oesophageal varices was the leading cause of upper digestive haemorrhage found in $57.6 \%$ of cases followed by peptic ulcer with $30.5 \%$ of cases, most likely because of the frequency of infection with the gastrointestinal ulcer. 
$\mathrm{HBV}$ and Helicobacter pylori infection in the general population. This finding confirms the study by Diarra et al. [13] who found respectively $55.2 \%$ and $12.8 \%$. These results are different from those of N'Tagirabiri et al. (28.2\% and 46.1\%) [15] and Razafimahefa et al. [8] who found 40.32\% PU and 38.76 indeterminate causes. In our study, no lesion in digestive endoscopy was found in $3.4 \%$ of cases, probably due to fugitive lesions by NSAIDs justifying the early inputs of endoscopy.

In 39 patients, a transfusion was indicated but it did not influence the prognosis $(\mathrm{p}=0,8308)$. The same observation was made by Maiga et al. [14]. The immediate course was favorable in $73 \%$ of the cases after a resuscitation associating with a vascular filling, an administration of PPI, an antibiotherapy, the hemostatic treatment not being available. This rate is not identical with those of Diarra et al. [13] and N'Tagirabiri et al. [15] which were respectively $77.6 \%$ and $77.1 \%$.

The mortality of digestive haemorrhages in our series was $14.3 \%$. Higher mortality was reported by Diarra et al. (22.4\%) [13] and N'Tagirabiri et al. (22.9\%) [15].

This mortality is linked in our series to the early recurrence of hemorrhage and also to the most often cirrhotic terrain whereas for Diarra et al. [13] and Razafimahefa et al. [8] it seems to be linked to certain lesions, in particular gastric tumors and rupture of oesophageal varices.

\section{Conclusion}

Acute high digestive hemorrhages remain frequent and serious in our context. The availability of specific hemostatic treatment could have reduced overall mortality. In addition, the prevention of infection with hepatitis viruses and the fight against self-medication could reduce the frequency and therefore the mortality of these accidents.

\section{Conflicts of Interest}

The authors declare no conflicts of interest regarding the publication of this paper.

\section{References}

[1] Lasserre, N., Duval, F. and Pateron, D. (2009) Upper Digestive Bleedings, Management into Emergency Services. Emergnecie, 98, 959-968.

[2] Hervé, S. (2007) Epidemiology of Upper Digestive Bleedings: New Aspects. Hepato-Gastro, 14, 205-210.

[3] Pateron, D. and Belhadj, K. (2001) Management of Acute Upper Digestive Bleedings: Hemostatic Medecine Use Prise en charge des hémorragies digestives aiguës hautes. Reanimation, 10, 666-672. https://doi.org/10.1016/S1164-6756(01)00175-X

[4] Hagège, H., Latrive, J.P., Nalet, B., et al. (2012) Communautary Uger Digestive Bleedings: Preliminary Results of the ANGH Study among under 1000 Patients. JFHOD, Paris, France. https://www.snfge.org/

[5] Ben Chaabane, N., Ben Youssef, H., Ghedira, A., et al. (2010) Epidemiology of Up- 
per Digestive Bleedings in Tunisia. Acta Endoscopica, 40, 176-182. https://doi.org/10.1007/s10190-010-0049-4

[6] Samlani Sebbane, Z., Gharaba, S., Krati, K., et al. (2012) Etiologicalprofile of Exteriorised UDB the Departement of Marrakech. Journal Africain d'Hépato-Gastroentérologie, 6, 256-258.

[7] Ye, M. (2001) Digestive Bleedings in Bobodioulasso National Hospital: Epidemiological, Clinical, Therapeutique and Evolutive Aspects. These, Med, Ouagadougou, 38.

[8] Razafimahefa, S.H., Rabenjanahary, T.H., Rakotozafindraibe, R., et al. (2011) Upper Digestive Bleedings: Clinical, Endoscopic et évolutive Aspect. About 62 Malgache Patients. La Revue Médicale de Madagascar, 1, 6-10.

[9] Bagny, A., Bouglouga, O., Djibril, M.A., et al. (2012) Etiological Profile of Upper Dgestive Bleeding at CHU-Campus of Lomé (Togo). Journal Africain d'Hépato-Gastroentérologie, 6, 38-42. https://doi.org/10.1007/s12157-012-0356-1

[10] Kodjoh, N., Hountondji, A. and Addra, B. (1992) The Upper Digestive Bleedings and Gastrduodenal Pathology in Tropical Internal Medical Service. Médecine $d^{\prime}$ Afrique Noire, 39, 25-30.

[11] Konate, A., Diarra, M.T., Souckho, A., et al. (2008) Digestive Bleedings by Esophgeal Varice. Mali Medical, 23, 32-35.

[12] Diarra, M., Konaté, A., Traore, C., et al. (2009) Gasroduodenal Ulcers in Rural Eria in Mali. Mali Medical, 24, 1-3.

[13] Diarra, M., Soucko-Diarra, A., Dolo, M., et al. (2007) Upper Acute Digestive Bleedings: Rural Experiency. Acta Endoscopica, 37, 321-326. https://doi.org/10.1007/BF02961922

[14] Maiga, M.Y., Dembelé, M., Gangaly, D., et al. (2002) The Uoper Acute Digestive Bleedings in Hospital. Mali Medical, 7, 5-8.

[15] N’ Tagirabiri, R., Mumana, A., Dunduri, D., et al. (2012) Upper Digestive Bleedinds in Adult in Burundi: Epidemiological, Etiological, Therapeutic and Evolutive Aspects. Journal Africain d'Hépato-Gastroentérologie, 6, 272-275.

[16] Zohra, M.F. (2011) Upper Digestive Bleedings at Emergencies at CHU Ibn Rochd of casablanca (About 50 Cases). These, Med, Fès, 055. 